\title{
IMPLEMENTASI ARTIFICIAL INFORMATICS PADA SISTEM INFORMASI KALENDER AKADEMIK DALAM PENYEBARAN INFORMASI DI PERGURUAN TINGGI
}

\author{
Muhamad Yusup ${ }^{1}$ \\ Augury El Rayeb ${ }^{2}$ \\ Sri Rahayu ${ }^{3}$ \\ e-mail : Muhamad.yusup@faculty.raharja.ac.id, \\ augury@faculty.raharja.ac.id,sri_rahayu@faculty.raharja.ac.id
}

Diterima :20 Januari 2011/Disetujui : 9 Februari 2011

\begin{abstract}
Academic calendar is a master plan for the implementation of academic activities within one year. With the academic calendar for each event held always $3 T$ namely Planned, Measured and well realized. But there are conditions that the scheduling of many who are ad hoc, there is no effective way of presenting scheduling and information presented in the academic calendar to all elements of academic community and eventually will affect the quality of activities and dissemination of information on higher education. Application of Artificial Informatics at the Academic Calendar Information System (SISKA) is a reminder every activity that had been scheduled to be computerized to all elements of academic community colleges. By utilizing a computer network infrastructure and email facilities that already exist, it is expected that each activity is scheduled to be sent automatically to every mailing list or email list at the universities through the concept of Auto Electronic Mailing System (AEMS). Artificial Informatics has a characteristic that is a virtual staff that has a job description like the staff college, so that worked tirelessly and forget to always take the job. Simply put, the definition of Artificial Informatics is an information system that has the character and capabilities as human beings by using a PC in helping to complete everyday tasks. With the application of Artificial Informatics in the academic calendar information system is expected to improve the quality of information dissemination and implementation of the activities at universities.
\end{abstract}

Keywords: Artificial Informatics, Reminder, Auto Electronic Mailing System (AEMS)

1. Dosen Jurusan Teknik Informatika, AMIK Raharja Informatika Jl. jend Sudirman No. 40 Modern Cikokol-Tangerang Telp. 5529692

2. Dosen Jurusan Sistem Komputer, STMIK Raharja

Jl. jend Sudirman No. 40 Modern Cikokol-Tangerang Telp. 5529692

3. Dosen Jurusan Sistem Informasi, STMIK Raharja

Jl. jend Sudirman No. 40 Modern Cikokol-Tangerang Telp. 5529692 


\section{ABSTRAKSI}

Kalender akademik merupakan rencana induk penyelenggaraan kegiatan akademik dalam kurun waktu satu tahun. Dengan kalender akademik setiap kegiatan yang diselenggarakan agar selalu $3 T$ yaitu Terencana, Terukur dan Terealisasi dengan baik. Namun kondisi yang ada bahwa penjadwalan banyak yang bersifat adhoc, belum ada cara yang efektif menyuguhkan penjadwalan dan informasi yang disajikan dalam kalender akademik kepada seluruh unsur civitas akademik hingga pada akhirnya akan mempengaruhi kualitas penyelenggaraan kegiatan dan penyebaran informasi pada perguruan tinggi. Penerapan Artificial Informatics pada Sistem Informasi Kalender Akademik (SISKA) merupakan bentuk reminder setiap kegiatan yang telah dijadwalkan secara komputerisasi kepada seluruh unsur civitas akademik perguruan tinggi. Dengan memanfaatkan infrastruktur jaringan komputer dan fasilitas email yang sudah ada, diharapkan setiap kegiatan yang sudah dijadwalkan akan terkirim secara otomatis kepada setiap milis atau daftar email di perguruan tinggi melalui konsep Auto Electronic Mailing System (AEMS). Artificial Informatics memiliki ciri khas yaitu virtual staff yang memiliki job description layaknya staf perguruan tinggi, sehingga tanpa lelah dan lupa bekerja untuk selalu memperhatikan tugasnya. Secara sederhana, definisi Artificial Informatics adalah sebuah sistem informasi yang memiliki karakter dan kapabilitas seperti manusia dengan menggunakan PC dalam membantu menyelesaikan tugas sehari-hari. Dengan penerapan Artificial Informatics pada sistem informasi kalender akademik diharapkan dapat meningkatkan kualitas dalam penyebaran informasi dan penyelenggaraan kegiatan pada perguruan tinggi.

Kata Kunci: Artificial Informatics, Reminder, Auto Electronic Mailing System (AEMS)

\section{PENDAHULUAN}

Kalender akademik merupakan rencana induk penyelenggaraan kegiatan akademik dalam kurun waktu satu tahun. Dengan kalender akademik setiap kegiatan yang diselenggarakan harus selalu terencana, terukur dan terealisasi dengan baik. Namun kondisi yang ada bahwa penjadwalan pada kalender akademik yang disajikan banyak yang bersifat adhoc, belum ada cara yang efektif menyuguhkan penjadwalan dan informasi yang disajikan dalam kalender akademik kepada seluruh unsur civitas akademik hingga pada akhirnya akan mempengaruhi kualitas penyelenggaraan acara atau kegiatan pada perguruan tinggi.

Analisa awal dimana informasi pada kalender akademik belum sepenuhnya ditemukannya metode yang tepat dalam menyajikan informasi dan penjadwalan yang ada di kalender akademik kepada seluruh civitas akademik perguruan tinggi yang meliputi unsur manajemen, dosen, mahasiswa serta alumni. Terkadang informasi dan penjadwalan sudah disampaikan berupa media seperti spanduk, mading, surat edaran, telepon reminder, serta sms reminder masih kurang cukup efektif sebagai 
media informasi dalam upaya meningkatkan frekwensi komunikasi. Belum ada metode dalam menjaga konsistensi penjadwalan apa saja yang akan atau sedang berlangsung. Selain itu rencana dalam satu tahun yang dituangkan ke dalam kalender akademik banyak yang terlupakan karena disibukan dengan kegiatan rutinitas perguruan tinggi. Sejalan konsep e-leadership berorientasi pada kegiatan pengarahan dan pendelegasian karena e-leadership menciptakan lebih banyak ruang keterbukaan dan frekwensi komunikasi antara bawahan dan manager, antara pimpinan perguruan tinggi dengan mahasiswa, karena akan lebih terbuka dalam menyampaikan pendapatnya secara tidak langsung dengan pimpinannya melalui media teknologi informasi. Seorang manajer dapat memberikan pengarahan dan pendelegasian tugas kepada bawahan dengan menggunakan berbagai media teknologi informasi misalnya email (Henderi, 2008).

Walaupun sudah ada media komunikasi dalam meningkatkan ruang keterbukaan dan frekwensi komunikasi namun dirasakan masih sulit untuk menjaga tingkat konsistensi penjadwalan dan fungsi kontrol dan pendelagasian dalam penyebaran informasi yang ada pada kalender akademik. Dengan menerapkan Artificial Informatics pada sistem kalender akademik dalam penyebaran informasi di perguruan tinggi diharapkan dapat menjaga konsistensi penjadwalan apa saja yang akan atau sedang berlangsung. Tugas pengontrolan, pendelegasian serta penyebaran informasi yang merupakan menyempurnaan dari konsep e-leadership akan semakin terjaga konsistensinya dengan mengoptimalkan peran virtual staff yang mempunyai job description terhadap peran yang harus diembannya.

Penelitian yang dilakukan untuk menjawab permasalahan yang dihadapi oleh salah satu kampus yang berlokasi di Tangerang tentang sebab dan akibat dari penyebaran informasi kalender akademik kepada seluruh unsur civitas akademik perguruan tinggi.

Penerapan Artificial Informatics pada Sistem Informasi Kalender Akademik (SISKA) merupakan bentuk reminder setiap kegiatan yang telah dijadwalkan secara komputerisasi kepada seluruh unsur civitas akademik perguruan tinggi. Dengan memanfaatkan infrastruktur jaringan komputer dan fasilitas email yang sudah ada, diharapkan setiap kegiatan yang sudah dijadwalkan akan terkirim secara otomatis kepada setiap milis atau daftar email di perguruan tinggi melalui Auto Electronic Mailing System (AEMS). Artificial Informatics memiliki ciri khas yaitu virtual staff yang mempunyai job description layaknya staff perguruan tinggi, sehingga tanpa lelah dan lupa bekerja untuk selalu memperhatikan tugasnya. Secara sederhana, definisi Articial Informatics adalah sebuah sistem informasi yang memiliki karakter dan kapabilitas seperti manusia dengan menggunakan PC dalam membantu menyelesaikan tugas sehari hari. Dengan penerapan Artificial Informatics pada SISKA 
diharapkan dapat meningkatkan kualitas informasi dan penyelenggaraan kegiatan pada perguruan tinggi.

Terdapat beberapa tahapan dalam mengidentifikasi masalah penelitian. Adapun langkah awalnya adalah dengan mengumpulkan bahan-bahan yang berguna bagi penelitian ini. Sumber bahan itu antara lain dari Bagian Akademik, Bagian Humas dan Bagian Keuangan, tentang data dan informasi yang sedang berjalan yang didapat dari Raharja Enrichment Center (REC). Literatur untuk penelitian didapat dari beberapa buku teks, untuk memperkaya wawasan juga dilakukan pencarian litelatur yang terkait dengan penelitian melalui Internet.

Langkah selanjutnya melakukan analisa terhadap masalah yang teridentifikasi dan menerjemahkan kedalam metodologi pemecahan masalah dengan sistem informasi. Melakukan rancangan sistem yang sesuai dengan metodologi pemecahan yang sudah diterjemahkan pada langkah sebelumnya. Langkah terakhir membangun suatu sistem informasi kalender akademik, membangun sistem AEMS, kemudian melakukan testing dan implementasi Artificial Informatics dalam bentuk virtual staff terhadap SISKA tersebut.

\section{RUMUSAN MASALAH}

Akibat penyebaran informasi yang tidak merata serta belum ditemukannya cara yang efektif dalam penyebaran informasi maka ditemukan masalah yang timbul berdasarkan kajian studi pustaka yang dilakukan tertuang didalam Laporan Bagian Keuangan dan pemasaran serta akademik salah satu perguruan tinggi di Tangerang seperti: teridentifikasi mahasiswa lupa dengan tanggal jatuh tempo pembayaran, mahasiswa yang tidak registrasi tepat waktu sekitar 14\% yang ditargetkan 25\% namun ini dirasakan masih cukup tinggi. Langkah penanganan sudah dilakukan seperti melakukan pengiriman surat pemberitahuan tunggakan SPP kepada orang tua mahasiswa ketika melewati batas jatuh tempo, melakukan peneleponan satu persatu terhadap mahasiswa jatuh tempo untuk melakukan follow up tunggakan, penerapan biaya keterlambatan, membuat pengumuman batas waktu pembayaran melalui mading dan spanduk, mengirimkan sms reminder satu persatu terkadang juga petugas lupa dan tidak konsisten melakukan reminder tersebut. Selain itu diberikan tembusan kalender akademik yang tercantum didalam surat edaran, namun cara ini dirasakan masih belum efektif karena ada beberapa kendala ditemukan seperti mahasiswa tidak mengetahui pengumuman walaupun informasi sudah ditempatkan di mading dan spanduk, nomor HP sudah tidak aktif, alamat tidak lengkap sehingga surat yang disampaikan tidak sampai ke alamat pengiriman (Maria, 2006). 
Konsep awal, stakeholder memerlukan pemahaman yang lebih baik tentang kepentingan strategis dari penyebaran informasi pada sistem informasi kalender akademik kepada seluruh civitas akademik perguruan tinggi, dampaknya pada peningkatan frekuensi komunikasi dan menyebaran infornasi dalam menunjang aktifitas penyelenggaraan pendidikan tinggi.

Hipotesis yang akan diuji atau dugaan yang akan dibuktikan adalah dengan menerapkan Artificial Informatics dalam bentuk virtual staff terhadap SISKAdalam penyebaran informasi di perguruan tinggi diharapkan dapat menjaga konsistensi penjadwalan apa saja yang akan atau sedang berlangsung. Tugas pengontrolan, pendelegasian serta penyebaran informasi akan semakin terjaga konsistensinya dengan mengoptimalkan peran virtual Staff yang mempunyai job description layaknya staff perguruan tinggi terhadap peran yang harus diembannya.

Batasan penelitian ini terdiri atas tiga lingkup penelitian. Lingkup penelitian pertama adalah membangun SISKA terintegrasi dengan Student Information Services (SIS), dengan membuat database dalam menampilkan seluruh aktifitas kegiatan kampus yang berjalan. Lingkup kedua adalah membangun Auto Electronic Mailing System (AEMS) yang akan melakukan penyebaran email otomatis yang diambil dari database SISKA kepada civitas akademik yang memiliki account email lokal (worldclient) atau account live@edu. Lingkup ketiga adalah fasilitas yang sudah ada dan mendukung terhadap penerapan Artificial Informatics dengan membangun virtual staff yang memilki karakter dan kapabilitas kerja untuk melakukan reminder informasi atau kegiatan kampus kepada seluruh unsur civitas akademik perguruan tinggi.

\section{MANFAAT}

Adapun manfaat diimplementasikan Artificial Informatics pada SISKA ini adalah :

1. Membangun Sistem Informasi KalenderAkademik (SISKA) terintegrasi dengan Student Information Services (SIS), selanjutnya membuat database dalam menampilkan seluruh aktifitas kegiatan kampus yang berjalan.

2. Membangun Auto Electronic Mailing System(AEMS) yang akan melakukan penyebaran email otomatis yang diambil dari database SISKA kepada civitas akademik yang memiliki account email yang terkirim melalui milis intranet (worldclient) ataupun melalui account live@edu.

3. Fasilitas yang sudah ada dan mendukung terhadap penerapan Artificial Informatics dengan membangun virtual staff yang memilki karakter dan kemampuan kerja untuk melakukan reminder informasi atau kegiatan kampus kepada seluruh unsur civitas akademik perguruan tinggi. 


\section{LITERATURE REVIEW}

\section{Artificial Informatics}

Secara sederhana, definisi Articial Informatics (AI) adalah sebuah sistem informasi yang memiliki karakter dan kapabilitas seperti manusia dengan menggunakan PC dalam membantu menyelesaikan tugas sehari hari(Rahardja, 2009). Konsep Artificial Informatics ini bagaimana pada akhirnya bisa diimplementasikan atau "commercialization". Bagaimana sebuah konsep dapat menjelma menjadi sebuah produk? Salah satu jawabannya adalah virtual staff. Apa itu virtual staff? virtual staff adalah suatu system informasi (SI) yang memiliki karakter, disiapkan khusus untuk menyelesaikan tugas rutin sebuah organisasi. Berarti SI ini harus memiliki wujud manusianya, memiliki nama, hobbi, perasaan dan lain lain yang disebut karakter (Ricardson, 2002).

\section{Ciri Khas dan manfaat AI dan VS}

7 (tujuh) Ciri khas dari seorang virtual staff(VS) dari sebuah Artificial Informatics (AI) adalah:

1. Sistem Informasi yang lebih "humanized"

2. Sistem Informasi yang telah dipersonalisasi.

3. Sistem Informasi yang memiliki karakter.

4. Sistem Informasi yang lebih entertaining.

5. Sistem Informasi yang memiliki kapabilitas atau kemampuan bekerja.

6. Sistem Informasi yang bukan dibeli, tapi diberi upah, sesuai dengan undang undang tenaga kerja.

7. Sistem Informasi yang memiliki database dan menggunakan jaringan serta aplikasi Web.



Gambar 1. Diagram Artificial Informatics 
Manfaatnya adalah Pencipta AI melalui Virtual Staff memiliki pendekatan unik kepada sistem informasi sehingga dapat memperlancar pendanaan atau penawaran terhadap perusahaan yang membutuhkan Sistem Informasi. Mengenai siklus supply and demand menggambarkan jika adanya sebuah perusahaan yang serius membutuhkan sistem informasi, akan berbondong bondong datang penawaran sistem informasi dari banyak perusahaan, yang sipencipta AI sebagai salah satu kandidat tender untuk dapat memenangkan kontrak.

Dari waktu ke waktu, stakeholder memang sudah terlalu bosan mendengarkan penawaran solusi IT, dan merasa kebingungan juga, bahwa diantara sekian banyak yang menawarkan solusi IT, siapakah yang terbaik. Indikator terbaik artinya harus paling murah dan juga paling bagus, dan kalau bisa paling menyenangkan, atau dengan kata lain, paling indah atau paling praktis.

Dari sekian banyaknya penawaran SI yang terkesan bosan, tampil si pencipta AI mempersembahkan virtual staff sebagai solusi IT. Bahwa yang ditawarkan bukanlah sebuah sistem informasi yang harganya sekian ratus juta, tapi seorang virtual staff yang harus digaji, yang memiliki kepribadian karakter yang sesuai dengan lingkungan stakeholder, dan juga memiliki kemampuan dan kapabilitas kerja yang bermanfaat oleh organisasi stakeholder. Penawaran yang unik ini selain menghemat pendanaan IT dari perusahaan itu, juga diyakinkan bahwa virtual staff ini akan menyelesaikan tugasnya jauh lebih bermutu daripada seorang real staff.

Sebagai contoh, sang virtual staff akan dengan penuh dedikasi menyelesaikan tugas dengan sopan dan ramah, tepat waktu, tak pernah lupa dan tanpa salah. Sang real staff jika dibandingkan akan dengan sikap yang kurang menghargai atasan, tidak tepat waktu, sering lupa, dan sering salah. Mungkin dengan gaji yang lebih murah, seorang virtual staff bisa menggantikan seorang real staff dan menyelesaikan tugas dengan lebih baik. Demikian sang Pencipta AI ini menawarkan solusi IT yaitu virtual staff kepada perusahaan yang membutuhkannya. Dapat diyakini bahwa sang pencipta AI dapat lebih memiliki kesempatan untuk memenangkan tender SI ini.

Segala bidang usaha atau kegiatan tidak dapat terlepas dari entertainment sehingga timbul istilah edutainment, sportainment, ecotainment, dan lain lain. Walaupun menjalankan ibadah setiap hari nya merupakan kewajiban umat manusia, namun ibadah yang biasanya dijalankan dengan cara membosankan itu akan dikeluhkan banyak orang. Sebaliknya ibadah yang disiapkan penceramah yang menyenangkan akan disukai banyak orang. Tak bisa dipungkiri, khususnya dalam pembinaan anak anak kecil, pembelajaran yang menyenangkan menjadi kunci keberhasilan suatu pendidikan anak. Contoh lain, aktifitas olah raga yang membosankan tidak akan diminati, dan akan dengan sendirinya gugur dan tidak lagi dilakukan orang. Hanya 
aktifitas olah raga yang penuh semangat dan menyenangkan itu yang membuat banyak dilakukan dan ditonton orang.

Bagaimana dengan orang yang bekerja pada suatu perusahaan. Bila dirasakan membosankan, pekerja itu tidak akan bertahan lama dan akan pindah. Sebagai contoh, Google Inc berkomitmen untuk menciptakan suasana kerja yang entertaining untuk para staffnya. Dan diyakinkan untuk yang akan datang, tempat kerja yang menyenangkan akan semakin banyak dalam upaya sebuah perusahaan memenangi persaingan dalam mempertahankan Sumber Daya Manusianya.

Hubungannya dengan Artificial Informatics, dengan produk virtual staff nya yang sukses, akan memiliki karakter yang cocok dengan SDM yang lain pada perusahaan tersebut, sehingga membuat SDM yang ada dalam hal bekerja lebih terasa "entertaining". Disimpulkan bahwa virtual staff merupakan suatu keharusan didalam sebuah organisasi, dalam rangka menambah kaya karakter dari perusahaan tersebut, dan merupakan karyawan yang tidak bisa digantikan karena fungsi penting yang dijalankan oleh virtual staff sesuai dengan wewenang dan tanggung jawabnya.

\section{METODOLOGI}

Untuk menerapkan Artificial Informatics pada Sistem Informasi Kalender Akademik (SISKA) dalam penyebaran informasi di Perguruan Tinggi, metode yang digunakan dalam penelitian meliputi variabel yang diteliti, model yang digunakan, rancangan penelitian, teknik pengumpulan data dan analisis data, cara penafsiran dan penyimpulan hasil penelitian. Pada beberapa bagian penelitian yang menggunakan metode kualitatif, dapat dijelaskan pendekatan yang digunakan, proses pengumpulan dan analisis informasi, proses penafsiran dan penyimpulan hasil penelitian.

Variabel Penelitian. Variabel pertama adalah kebutuhan informasi kalender akademik. Variabel kedua adalah spesifikasi fitur-fitur untuk merancang sistem informasi kalender akademik. Variabel ketiga adalah penerapan Artificial Informatics pada Sistem Informasi Kalender Akademik dan Variabel keempat adalah email otomatis menggunakan AEMS.

Model yang digunakan. dipakai model dari sistem informasi yang mempunyai peran kompetitif. Menyediakan nilai ke customer atau constituent adalah tujuan utama setiap manajemen. Nilai-nilai itu antara lain kualitas pada biaya rendah, fiturfitur unik dan/atau ketersediaan segera atau layanan penyebaran informasi secara konsisten.

Rancangan penelitian. Penelitian dirancang dengan memanfaatkan semua sumber daya yang sudah tersedia di Raharja Enrichment Center, mengintegrasikan 
komponen-komponen sistem informasi yang masih terpisah, meningkatkan kualitasnya.

Teknik Pengumpulan Data. Teknik pertama adalah LTK (Learn to Know), LTL (Learn to Learn), LTLT (Learn to Live Together), LTD (Learn to Do), dan LTB (Learn to Behave). Teknik kedua adalah mengidentifikasi permasalahan penyebaran informasi, manajemen database, sistem email otomatis, dan penerapan Artificial Informatics. Teknik ketiga adalah mengkalkulasi parameter optimasi penyebaran informasi pada Sistem Informasi Kalender Akademik.

Teknik Analisa Data. Teknik pertama adalah memahami masalah, formulasi, program (unified modeling language, algoritma, penulisan source code), test, dokumentasi. Teknik kedua adalah maximize the existing tool and capability of laboratory, minimize the idle equipment and wasting time. Teknik ketiga adalah managing existing equipment (maximize the useful of equipment, periodically calibration, periodically report of the equipment condition, historical condition of the important and costly equipment). Teknik keempat adalah managing the staff (organizing the staff/routine meeting, job description, upgrading the skill, distribute the new information as soon as possible). Teknik kelima adalah managing the project (time tabling the routine job [student practice, student project, lecturer research], time tabling the side job [training, workshop, services, etc]). Teknik keenam adalah development (refresh the staff, updating the equipment, create new innovation especially for the current trends).

Cara penelitian dan penafsiran. Cara pertama adalah menganalisis penggunaan sistem informasi untuk meningkatkan keputusan. Cara kedua adalah otomasi keputusan. Cara ketiga adalah menstrukturkan proses-proses keputusan. Cara keempat adalah mendukung kerja analitis. Cara kelima adalah empowering people, reorganizing work flows, automating work, dan integrating across functions.

Pada beberapa bagian penelitian yang menggunakan metode kualitatif, pendekatan yang digunakan dengan perencanaan sistem informasi, the system life cycle, issues addressed by different development processes, prototype, application packages, end-user development, selecting system life cycles, dan supporting end users. Proses pengumpulan dan analisis informasi dengan cara tailored mode sesuai particular system setting. Proses penafsiran dan penyimpulan hasil penelitian dengan cara berpikir logis, berpikir kreatif seperti melihat proses pemecahan masalah, meletakkan dasar, curah gagasan, kumpulkan pengetahuan dari tempat lain, melihat situasi dari semua sisi, mengubah posisi sesering mungkin. 


\section{HASIL DAN PEMBAHASAN}

Kalender akademik diterbitkan melalui keputusan pimpinan perguruan tinggi selanjutnya Kalender Akademik tersebut didistribusikan kepada Civitas Akademika pada setiap awal tahun akademik. Untuk tahun 2010/2011 ini Kalender Akademik ditetapkan berdasarkan SK Direktur Nomor: 612/SK-PENETAPAN/PT/VI/2010 tentang Penetapan Kalender Akademik 2010/2011. Kalender Akademik adalah Jadwal Kegiatan Perguruan Tinggi Raharja selama 1 (satu) tahun akademik yaitu setiap tanggal 1 September dan berakhir pada tanggal 31 Agustus, yang meliputi jadwal Registrasi, Perkuliahan, Ujian, Libur Perkuliahan dan jadwal kegiatan lainnya yang dapat dipergunakan oleh seluruh civitas Perguruan Tinggi.

Adapun tujuan disusunnya kalender ini dalam rangka meningkatkan kualitas penyelenggaraan pendidikan pada Perguruan Tinggi, serta untuk kelancaran proses perkuliahan, maka dipandang perlu adanya penetapan Kalender Akademik ini. Kalender Akademik ini disusun dengan memperhatikan hasil rapat akademik serta disposisi dari Pimpinan Perguruan Tinggi serta dengan memperhatikan Surat Keputusan Bersama (SKB) Menteri tentang Hari Libur Nasional dan Cuti Bersama. Pada kondisi sistem yang berjalan, Kalender akademik didistribusikan kepada dosen oleh Humas berupa lembaran kertas sebagai media penyebaran informasinya. Sehingga ditemukan beberapa permasalahan seperti yang telah digambarkan sebelumnya.

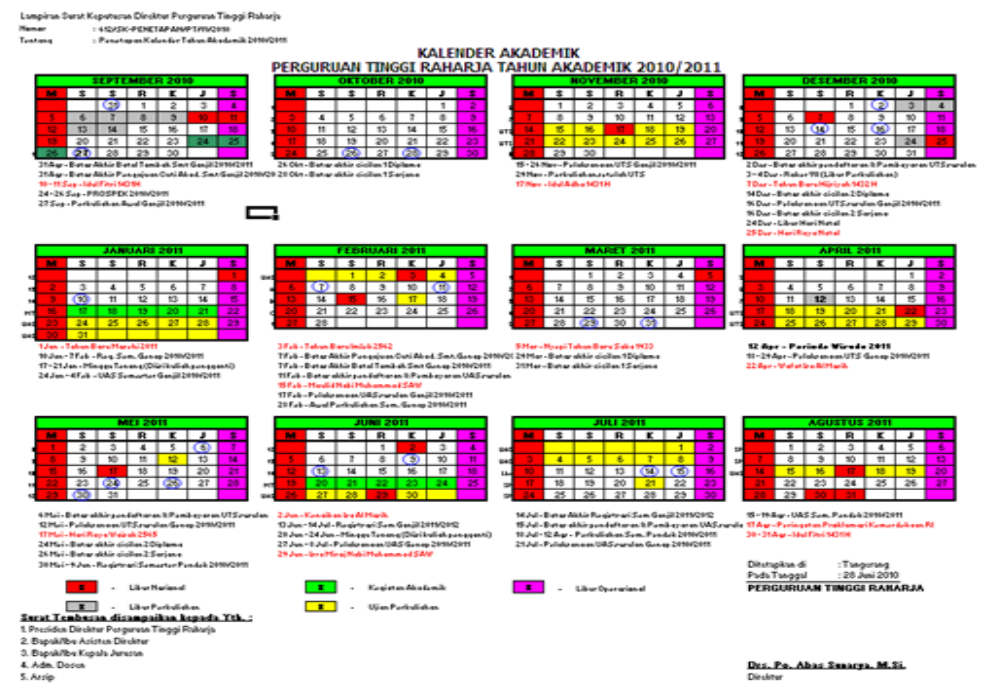

Gambar 2. Kalender Akademik 
Kalender akademik pada proses sistem yang berjalan dibuat dengan cara manual menggunakan program spreedsheet. Untuk membuat sistem yang diusulkan, dilakukan analisa terhadap Sistem informasi Kalender Akademik. Pada penelitian ini menggunakan program Visual Paradigm for UML 4.0. yang digambarkan ke dalam diagram, diantaranya Use Case Diagram dan Class Diagram. Berikut ini adalah analisa sistem menggunakan Use Case Diagram:

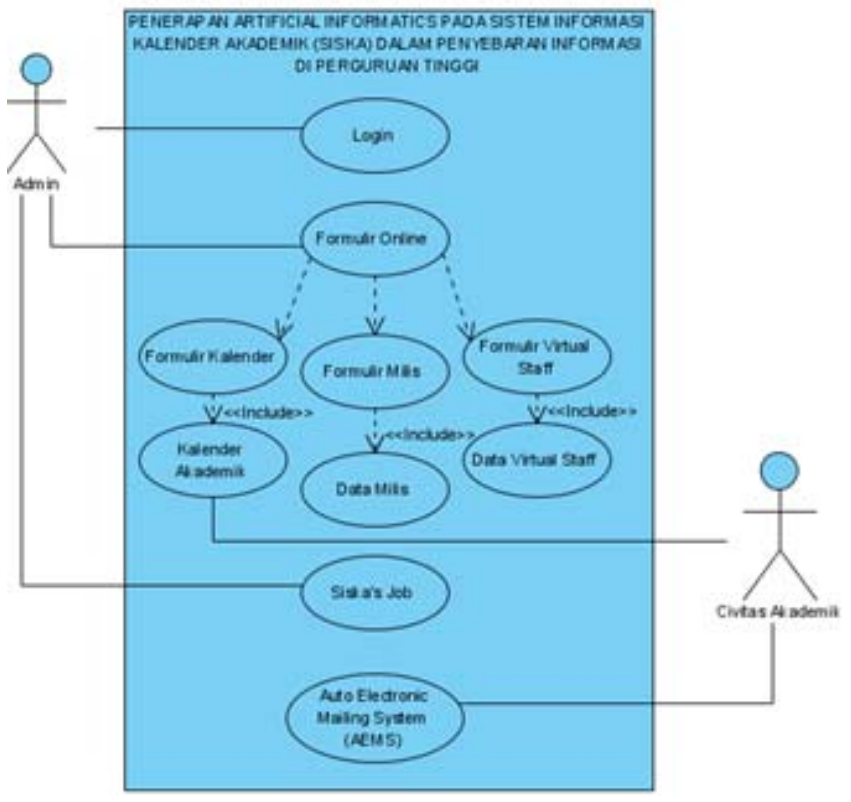

Gambar 3. Use Case Diagram pada SISKA

Berdasarkan Gambar 4. Use Case Diagram pada Sistem Informasi Kalender Akademik terdapat:

a. Sebuah sistem yang mencakup seluruh kegiatan pada Penerapan Artificial Informatics pada Sistem Informasi Kalender Akademik dalam Penyebaran Informasi di Perguruan Tinggi.

b. 2 actor yang melakukan kegiatan, yaitu Admin dan Civitas Akademik Perguruan Tinggi.

c. 10 use case yang biasa dilakukan oleh actor-actor tersebut diantaranya login, menambahkan informasi pada kalender akademik, menentukan kepada milis 
apa saja informasi kalender akademik itu disebarkan, membuat data virtual staff, menentukan Siska's jobs sebagai fungsi reminder.

d. 3 include yang menspesifikasikan use case.

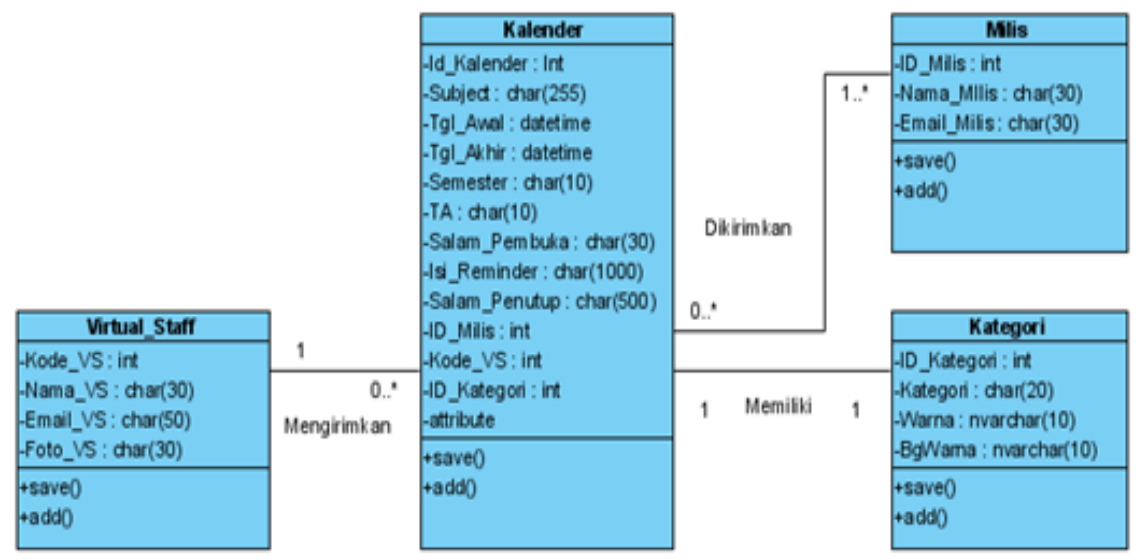

Gambar 4. Class Diagram pada SISKA

Berdasarkan gambar 4 Class Diagram terdapat:

a. 4 class, himpunan dari objek-objek yang berbagi atribut serta operasi yang sama.

b. 3 multiplicity, hubungan antara objek satu dengan objek lainnya yang mempunyainilai.

Selanjutnya merancang tampilan program dibuat dalam bentuk web based tujuannya memudahkan admin dan Civitas Akademik mengakses sistem informasi kalender akademik kapan saja dan dimana saja selain dalam bentuk reminder email. Kalender Akademik ditampilkan perbulan yang dilengkapi dengan navigasi menuju bulan sebelumnya atau bulan berikutnya. Kalender Akademik juga ditampilkan dalam bentuk tabel dengan kolom terdiri dari subject kalender, tanggal awal pelaksanaan, tanggal akhir pelaksanaan, semester serta tahun akademik. 


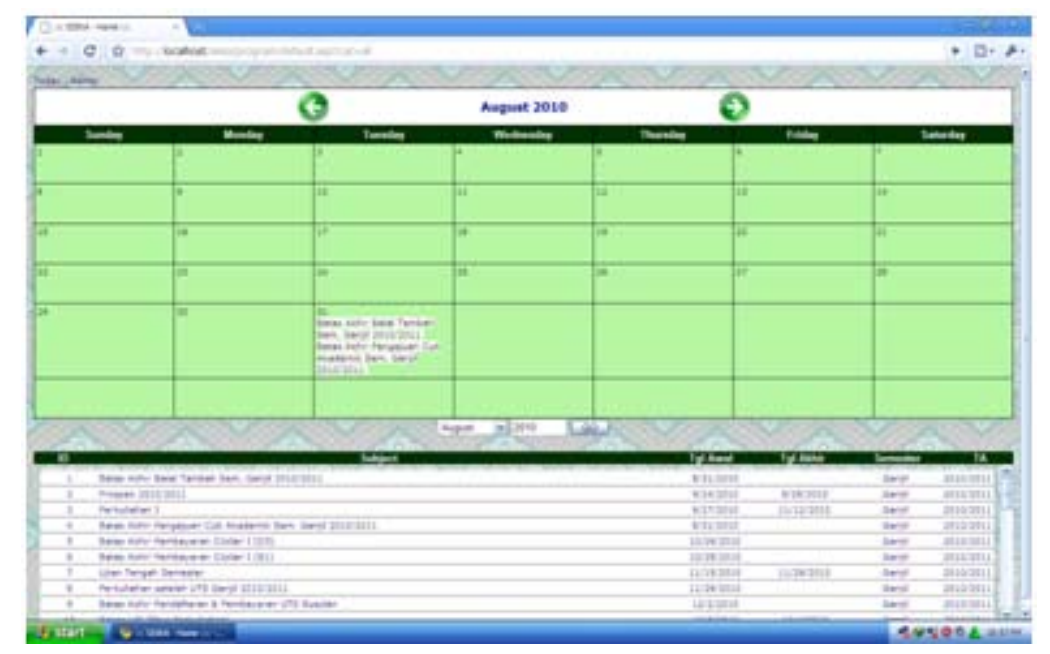

Gambar 5. Tampilan halaman program

Potensi Diimplementasikannya Artificial Informatics pada Sistem Informasi Kalender Akademik (SISKA) dalam Penyebaran Informasi di Perguruan Tingggi adalah dengan dikeluarkannya Surat Keputusan Direktur penggunaan email yang menjadikan live@edu sebagai jalur komunikasi resmi di lingkungan Perguruan Tinggi Raharja, dengan SK Direktur Nomor: 772/SK-IMPLEMENTASI/PT/XI/2009.

a. Media pengumuman Kalender Akademik yang wajib diketahui oleh seluruh Civitas Akademik Perguruan Tinggi Raharja

b. Media informasi kegiatan manajemen Perguruan Tinggi Raharja

c. Media komunikasi antar Kepala Jurusan dengan dosen binaan.

d. Media komunikasi antar Kepala Jurusan dengan mahasiswa di jurusannya.

e. Media koordinasi antar Bagian atau Divisi.

f. Media komunikasi antar organisasi kemahasiswaan.

g. Media kritik dan saran

Dengan adanya landasan hukum yang menjelaskan bahwa email sebagai salah satu media pengumuman kalender akademik kepada seluruh civitas akademika, akan lebih optimal perannya jika menggunakan virtual staff dalam penyebaran informasi. Tahap selanjutnya membangun AEMS (Auto Electronic Mailing System) AEMS pada proses pengiriman informasi melalui email: 


\section{DECLARE}

@out_desc VARCHAR(1000),

@out_mesg VARCHAR(10)

DECLARE@subject NVARCHAR(255),

@ttgl_awal datetime,

@salam_pembuka NVARCHAR(30),

@isi_reminder NVARCHAR(500),

(a)salam penutup NVARCHAR(200),

@nama_milis NVARCHAR(30),

@email_milis NVARCHAR(30),

@nama_vs NVARCHAR(30),

@email_vs NVARCHAR(30),

@)foto_vs NVARCHAR(30)

DECLARE@body NVARCHAR(1000)

DECLARE C1 CURSOR READ ONLY

FOR

SELECT

subject,

tgl_awal,

salam_pembuka,

isi_reminder,

salam_penutup,

nama_milis,

email_milis,

nama_vs,

email_vs,

foto vs

FROM Reminder

\section{OPEN C1}

FETCH NEXT FROM C1 INTO

@subject,@tgl_awal,@salam_pembuka,@isi_reminder,@salam_penutup,

@nama_milis,@email_milis,@nama_vs,@email_vs,@foto_vs

WHILE@@FETCH_STATUS=0

BEGIN

IF DATEPART(DAY,@tgl_awal)=DATEPART(DAY,GETDATE()) 
AND DATEPART(MONTH,@tgl_awal)=

DATEPART(MONTH,GETDATE())

ANDDATEPART(YEAR,@tgl_awal)=DATEPART(YEAR,GETDATE())

\section{BEGIN}

SET@body=@salam_pembuka +' $<$ br $/>$ ' + @isi_reminder + ' $<$ br $/>$ ' + @salam_penutup + '<br $/><$ br $/><$ img src="http://localhost/siska/program/ images/'+@foto_vs+"'” $><$ br $/>$ '+@nama_vs

EXEC sp_send_mail

@email_vs,

@email_milis,

(a)subject,

@body,

'htmlbody',@output_mesg=@out_mesgoutput,@output_desc= @out_descoutput

\section{PRINT@out mesg}

PRINT@out_desc

\section{END}

FETCH NEXT FROM C1 INTO

@subject,@tgl_awal,@salam_pembuka,@isi_reminder,@salam_penutup, @nama_milis,@email_milis,@nama_vs,@email_vs,@foto_vs

END

\section{CLOSE C1}

DEALLOCATE C1

Berikut ini bentuk reminder yang dilakukan oleh virtual staff dalam mengirimkan pesan yang bersumber dari Kalender Akademik.

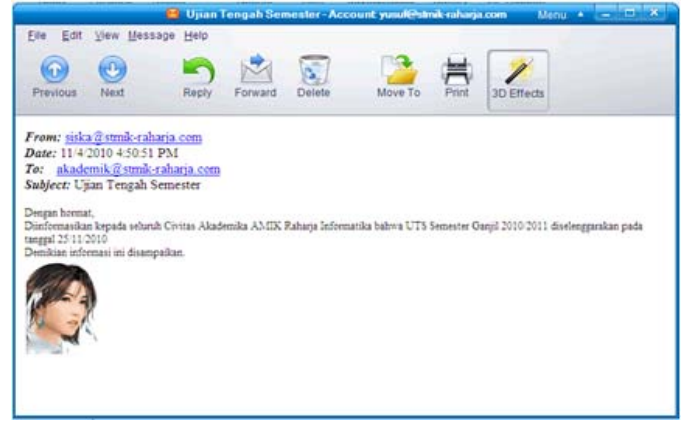

Gambar 6. Tampilan halaman program 


\section{KESIMPULAN}

Penerapan Artificial Informatics pada Sistem Informasi Kalender Akademik (SISKA) merupakan bentuk reminder setiap kegiatan yang telah dijadwalkan secara komputerisasi kepada kepada seluruh unsur civitas akademik perguruan tinggi. Reminder tersebut merupakan peran dari virtual staff yang memiliki kapabilitas kerja merupakan ciri khasnya dalam menjaga konsistensi penyebaran informasi dengan memanfaatkan infrastruktur jaringan komputer dan fasilitas email yang sudah ada, pada akhirnya penerapan ini dapat meningkatkan kualitas penyebaran informasi serta penyelenggaraan kegiatan pada perguruan tinggi.

\section{PUSTAKA}

1. Henderi, "E-Leadership: Konsep dan pengaruhnya terhadap efektivitaskepeminpinan," CCIT Journal, Tangerang Indonesia, vol.1 no.2, pp. 165 -172, Januari 2008.

2. K. Maria, "Laporan pertanggung Jawaban Divisi Keuangan dan pemasaran.” Tangerang: Perguruan Tinggi Raharja, 2006.

3. R. Untung, “Artificial Informatics”. Perguruan Tinggi Raharja, IEEE Transl, May 2009 [at the 4th IEEE Conference on Industrial Electronics and Applications Xi'an China, 2009].

4. F. M. Richardson, N. Davey, L. Peters, D. J. Done, S. H. Anthony, "Connectionist models investigating the representations formed in the sequential generation of characters", University of Hertfordshire, 2002. 